\title{
Sea-temperature anomalies and population dynamics variations: effects on growth and density of three bivalves
}

\author{
Alain Menesguen \& Luc Dreves \\ IFREMER, Centre de Brest, Département DERO/EL, BP 337, F-29273 Brest Cédex, France
}

\begin{abstract}
The demographic structure of stable populations is usually modelled by a simple exponential decay model. For 3 mollusc species, this model has been improved by taking into account monthly sea-temperature anomalies calculated on a 20 yr daily temperature chronicle. For the 3 species examined, Tapes rhomboïdes, Glycymeris glycymeris and Spisula ovalis, from the southern part of the Western English Channel, only temperature anomalies during the 2 mo following the major spawning period were positively correlated with density anomalies, probably in connection with larval stage sensitivity. Comparison of temperature anomalies and mean annual growth variability suggests an apparent positive effect of temperature during autumn or winter months, significant for $T$. rhomboides only. In spring and summer, temperature anomalies were negatively correlated with annual growth; although this phenomenon did not reach statistical significance, it may be linked with the well-known competition between gonadic development and somatic growth.
\end{abstract}

\section{INTRODUCTION}

The study of fisheries has emphasized that there are close correlations between climatic evolution and natural stock fluctuations. In his review, Cushing (1982) gives several examples of latitudinal oscillations of populations according to 'warm' or 'cold' periods: for instance during the recent warming (1925 to 1975), cod populations moved north and reached west Greenland, while pilchard coming from the south invaded the English Channel.

Independent of such major secular trends, yearly fluctuations have also been intensively studied. Based on the analysis of sequences of tree-ring widths, dendroclimatology has built up a complete methodology for treating such bioclimatological interactions. First, a regressive model based on well-documented periods has to be established, which can explain the observed growth of trees in terms of a few climatic features. Then, this regressive model may be used in an inverse mode to estimate the sequence of paleoclimatic fluctuations (Fritts 1976). Based on historical chronicles rather than on direct observation of biological material, a similar approach was carried out for vineyards in Western Europe. A significant, positive correlation was discovered between temperatures dur- ing the vegetative period (spring and summer) and earliness of the crop, as well as between AugustSeptember temperatures and the quality of the wine (Leroy-Ladurie 1983).

For marine species, yearly temperature anomalies show a positive correlation with annual recruitment at the northern limits of the distribution areas, while they are negatively correlated at the southern frontier; the case of cod has been intensively studied (Hermann et al. 1965, Martin \& Kohler 1965, Dickson et al. 1973). Many authors have dealt essentially with thermal aspects of climate, considering annual (Martin \& Kohler 1965) or monthly temperature means. Determination of the months showing maximal temperature effects regularly indicated that months corresponding to larval pelagic stages were the most sensitive (Dickie 1955, Hermann et al. 1965). With regard to this apparent effect of temperature on population characteristics, 2 main mechanisms have been invoked. The first is a direct effect on larval stage duration: high temperatures stimulate metabolism and growth and, hence, allow larvae to metamorphose faster and to escape pelagic predation and dispersion (Loosanoff et al. 1951, Dickie 1955). The second mechanism is indirect and mediated through the pelagic trophic chain: positive anomalies of heat budget at the sea surface 
can accelerate spring blooming of phytoplankton and provide a more favourable trophic environment for larvae emerging in spring. This theory of 'match-mismatch' has been developed by Cushing (1970) for fishes, especially herring. The purpose of this paper is to discuss correlations between annual temperature anomalies and fluctuations of density and individual growth of 3 benthic populations of molluscs.

\section{MATERIALS AND METHODS}

Populations under study. Within the framework of a large scale survey of the Gulf of St. Malo located in the Western English Channel (Fig. 1), a study of the most important populations of bivalves had been conducted (Blanchard et al. 1983). Three species are considered here: Tapes rhomboïdes (Pennant 1777, Spisula ovalis (Sowerby 1817) and Glycymeris glycymeris (Linné). Sampling was carried out with a Smith-McIntyre grab $\left(0.1 \mathrm{~m}^{2}\right)$ for $T$. rhomboïdes and $S$. ovalis, while an experimental dredge with $15 \mathrm{~mm}$ spacing was used for G. glycymeris. Sampling stations, indicated by $T$ for $T$. rhomboïdes, G for G. glycymeris and S for S. ovalis are shown in Fig. 1. For the first 2 species, several sampling dates (cf. Table 1) were pooled, and an a posteriori

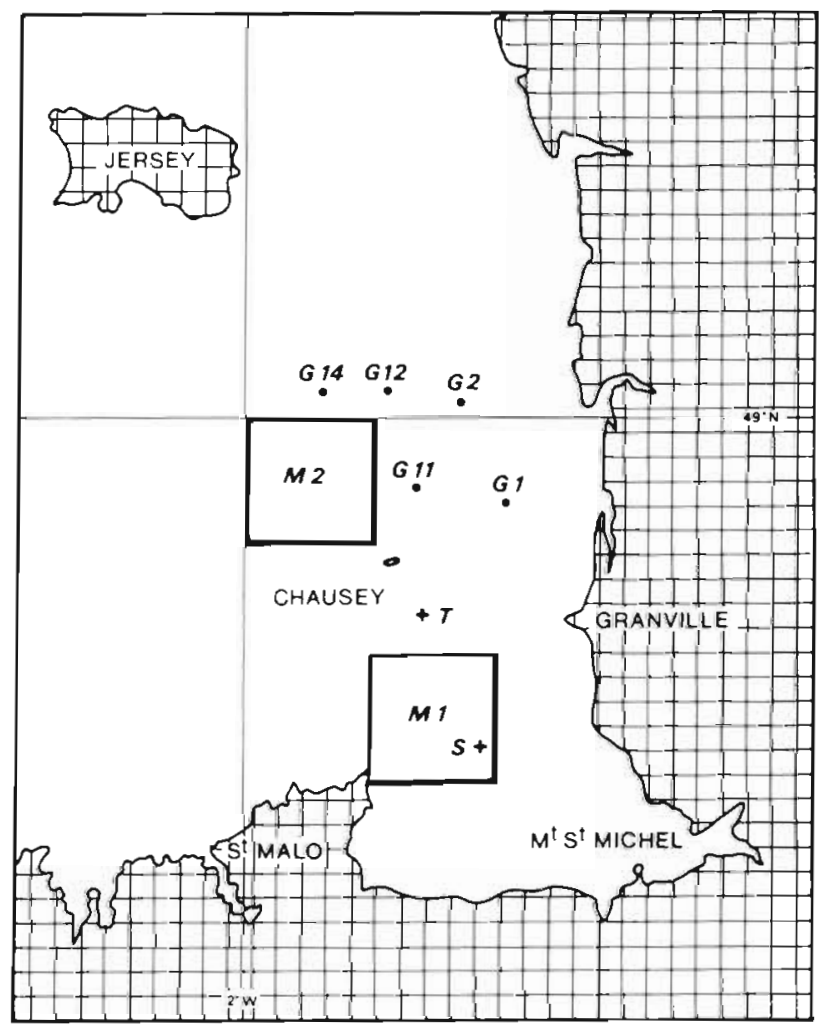

Fig. 1. Map of the Gulf of St. Malo showing location of the sampling stations
Table 1. Tapes rhomboïdes and Spisula ovalis. Sampling program

\begin{tabular}{|lcc|}
\hline Dates & $\begin{array}{c}\text { Tapes } \\
\text { rhomboïdes }\end{array}$ & $\begin{array}{c}\text { Spisula } \\
\text { ovalis }\end{array}$ \\
\hline 21 Oct 1980 & 10 grabs & \\
27 Jan 1981 & 10 grabs & 10 grabs \\
26 Feb 1981 & 10 grabs & 10 grabs \\
27 Mar 1981 & 7 grabs & 7 grabs \\
28 May 1981 & 10 grabs & 10 grabs \\
\hline
\end{tabular}

correction made to account for mortality between the different sampling dates and the most recent one. If $\mathrm{Z}$ is the instantaneous rate of decay of the population and $\Delta t$ is the time elapsed between one sampling date and the last date of the sampling program, abundances are multiplied by the factor $\exp (-\mathrm{Z} \Delta \mathrm{t})$. For G. glycymeris, all dredge samples from Stns 1, 2, 11 and 12 were pooled for demographic study, and only aged 6 yr or older classes were considered, since this dredge is known to underestimate younger year classes (Blanchard et al. 1983). The study of the growth of $G$. glycymeris required the examination of only one dredge sample (Stn 14), since numerous ring sizes were supplied by each specimen.

Determination of age and annual growth. Aging was done by counting the annual growth rings on the shells. Due to uncertainty at the beginning (first growth ring partially eroded) and end of life of old individuals, a double counting was performed by 2 persons working independently. In case of disagreement, a third counting was done by the 2 persons together. A second, numeric validation procedure was applied to the old individuals, to detect a missed first growth ring, by testing the estimated $t_{0}$ of the individual Von Bertalanffy growth curve (see later). When the age (yr) at the first visible growth ring is set equal to zero, the estimated $t_{0}$ must lie between -1 and 0 , with values lower than -1 corresponding to an underestimation of age (i.e. the first growth ring has not been detected). Individual pattern of growth was appraised through measurement of individual length at successive growth rings. Measurement to the nearest $0.5 \mathrm{~mm}$ was done only when the size increment after the current ring was greater than $1 \mathrm{~mm}$.

Modelling demographic structure and its fluctuations. On the assumption that the recruitment of a species is stable from year to year, a traditional exponential decay model may be fitted to the abundances of successive year classes found in a sample. To improve the estimation of the instantaneous rate of decay, the stability hypothesis can be abandoned and recruitment made dependent on an external environmental vari- 
able. Here, we suppose that recruitment is temperature-dependent and, based on the exponential effect of temperature on biological processes, we choose an exponential dependence of annual recruitment on the temperature anomaly during that year. The complete decay model is

$$
\mathrm{N}_{\mathrm{t}}=\left[\mathrm{N}_{\mathrm{o}} \cdot \exp \left(\alpha \cdot \Delta \theta_{-t}\right)\right] \cdot \exp (-\mathrm{Zt})
$$

where $N_{0}=$ mean annual recruitment, corresponding to the mean thermic year; $\alpha=$ a constant; $\Delta \theta_{-\mathrm{t}}=$ temperature anomaly during the birth-year; $\mathrm{Z}=$ instantaneous rate of decay.

A least squares estimate of the 3 parameters $N_{o} \alpha$ and $\mathrm{Z}$ is obtained by linearization (log-transform) of this model:

$$
\log N_{t}=\log N_{0}+\alpha \Delta \theta_{-t}-Z t
$$

This bilinear model expressing $\log N_{t}$ in terms of age $\mathrm{t}$ and climatic anomaly $\Delta \theta_{-\mathrm{t}}$ at the birth of the yearclass (for precise definition of climatic anomaly, see later) allows us to perform a classical test of significance by means of ANOVA. The thermal anomaly during a precise, a priori chosen month will be considered significantly correlated with the intensity of recruitment if the corresponding empirical F-ratio is greater than a critical value obtained from F-tables. The degrees of freedom are 1 for numerator and $(n-3)$ for denominator, $\mathrm{n}$ being the number of year classes taken into account. However, corresponding to a $95 \%$ level of significance for the test of a specific month will be only a $100 \times(0.95)^{12}=55 \%$ overall test of significance for the global climatic factor. Conversely, an overall test at the $95 \%$ level of significance would require a very high level of confidence for the test of a particular month, i.e. $100 \times(0.95)^{1 / 12}=99.573 \%$.

Modelling growth and its annual anomalies. As long as we are only concerned with a mean growth curve for the population, the measurement of a single parameter per individual (e.g. the actual length) is necessary in order to preserve stochastic independence between data and, hence, statistical inference facilities. However, if subtle growth anomalies are to be studied, examination of the individual pattern of growth becomes indispensable in order to filter individual genetic variability. In the same way as in dendrochronology, where only deviations from a mean individual trend of tree-ring succession are considered ('standardization', Fritts 1976), we first fit a Von Bertalanffy growth curve to the global trend of growth for each individual, and then consider annual deviations from this trend. The Von Bertalanffy growth curve, in the form given by Eqn (3), has been fitted using the BGC3 algorithm (Tomlinson 1970).

$$
\mathrm{L}_{\mathrm{t}}=\mathrm{L}_{\infty}\left(1-\exp \left(-\mathrm{K}\left[\mathrm{t}-\mathrm{t}_{\mathrm{o}}\right]\right)\right)
$$

However, it is well-known that unconstrained fitting gives unduly high values for $\mathrm{L}_{\infty}$ when young individuals are concerned, which are still in the first, quasilinear, growth period. For that reason, the study of growth anomalies had to be empirically restricted to individuals older than the age at which the mean growth curve for the whole population reaches $75 \%$ of $\mathrm{L}_{\infty}$. An individual estimation of the parameter $\mathrm{K}$ between ring $j$ and ring $(j+1)$ will then be obtained for the ith individual by:

$$
\mathrm{K}_{j \rightarrow j+1}^{(\mathrm{i})}=\log \frac{\mathrm{L}_{\infty}^{(\mathrm{i})}-\mathrm{L}_{j}^{(\mathrm{i})}}{\mathrm{L}_{\infty}^{(\mathrm{i})}-\mathrm{L}_{\mathrm{j}+1}^{(\mathrm{i})}}
$$

where $\mathrm{L}_{j}^{(\mathrm{i})}=$ individual length at ring $\mathrm{j}_{;} \mathrm{L}_{j+1}^{(1)}=$ individual length at ring $\mathrm{j}+1$.

A global estimation of parameter $\mathrm{K}$ on the whole population for a specific year has been calculated by adding up weighted individual estimations, the weight being proportional to theoretical size increment of the current individual during that year:

$$
\tilde{K}_{k}=\frac{\sum_{j=1}^{n}\left(\hat{L}_{j+1}^{(i)}-\hat{L}_{j}^{(i)}\right) \times K_{j \rightarrow j+1}^{(i)}}{\sum_{i=1}^{n}\left(\hat{L}_{j+1}^{(i)}-\hat{L}_{j}^{(i)}\right)}
$$

where $\hat{\mathrm{L}}_{\mathrm{j}}^{(1)}=\mathrm{L}_{\infty}^{(\mathrm{i})}\left(1-\exp \left(-\mathrm{K}^{(\mathrm{i})} \cdot\left[\mathrm{t}_{\mathrm{j}}-\mathrm{t}_{\mathrm{o}}\right]\right)\right)$

$$
\hat{\mathrm{L}}_{\mathrm{j}+1}^{(\mathrm{i})}=\mathrm{L}_{\infty}^{(\mathrm{i})}\left(1-\exp \left(-\mathrm{K}^{(\mathrm{i})} \cdot\left[\mathrm{t}_{\mathrm{j}+1}-\mathrm{t}_{\mathrm{o}}\right]\right)\right) \text {. }
$$

Index $\mathrm{i}$ refers to individuals (total sample size $=\mathrm{n}$ ); index $\mathrm{j}$ refers to the rank of the ring which begins the year under study on the shell of the ith individual; index $\mathrm{k}$ refers to the year under study.

Finally, we tried to find a simple linear correlation between the yearly estimates of $\mathrm{K}$ and concomitant thermal anomalies.

Calculation of temperature anomalies. As previously mentioned, several authors have used monthly temperature anomalies, defined as the deviation between the mean of a month in a specific year and the overall mean for the same month computed on a secular basis (Hermann et al. 1965, Dickie 1955). The same approach has been followed in our study, considering the plausible duration of larval stages (2 or $3 \mathrm{wk}$ ) and the natural spread of spawning period. The temperature data used for overall means and yearly anomaly evaluations were calculated by a numerical model of the heat budget of the whole English Channel (Agoumi 1982). Calibrated, this model is able to predict daily temperatures anywhere in the Channel from meteorological data recorded at La Hague meteorological station on the English Channel coast of France. Two meshes of the numerical model have been selected and temperatures calculated on a daily basis during the period from 1962 to 1983. Mesh M1 (Fig.1) has been used for the Spisula ovalis population and Mesh M2 for Tapes rhomboïdes and Glycymeris glycymeris. Temperature anomalies for Mesh 2 are shown in Fig. 2. 

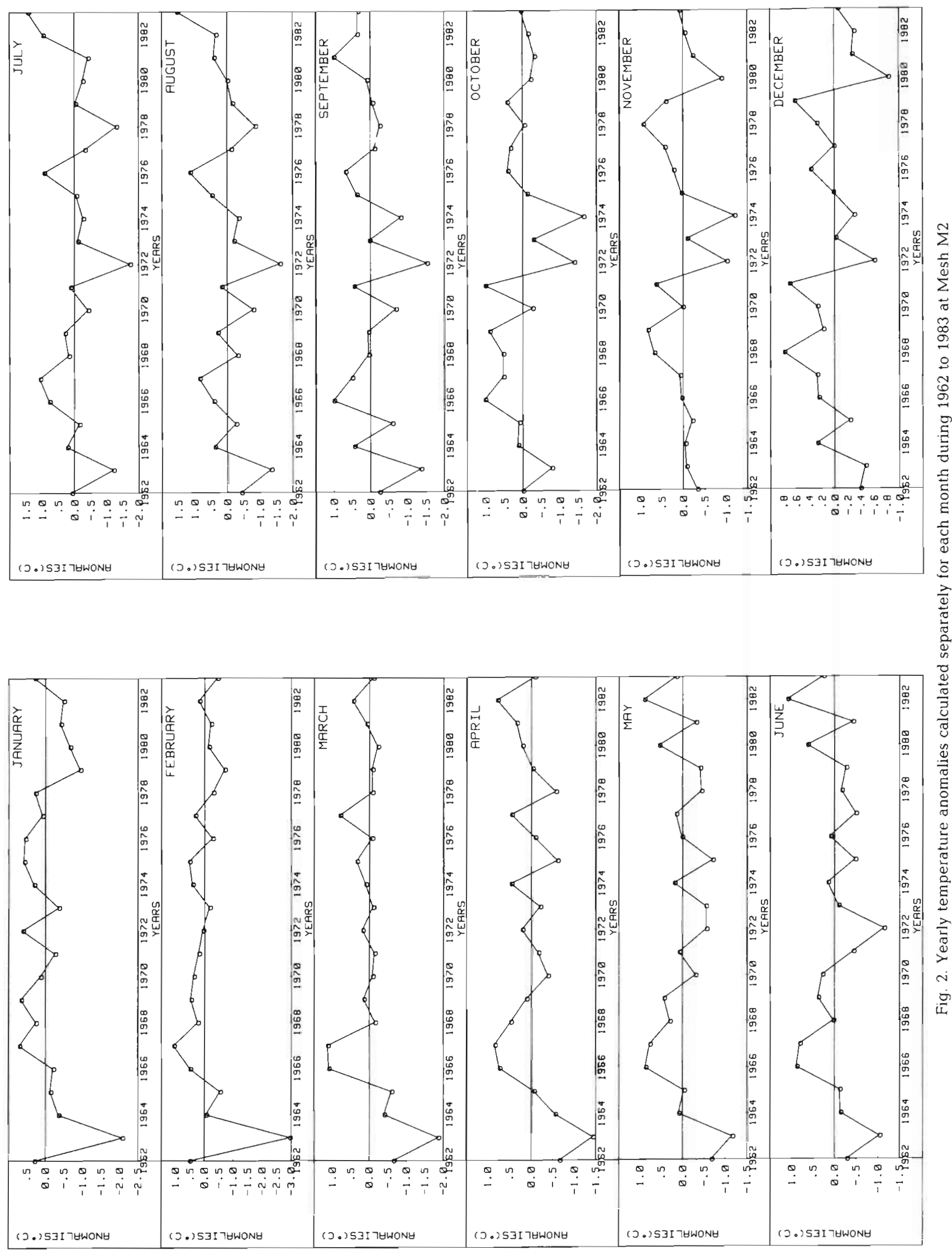


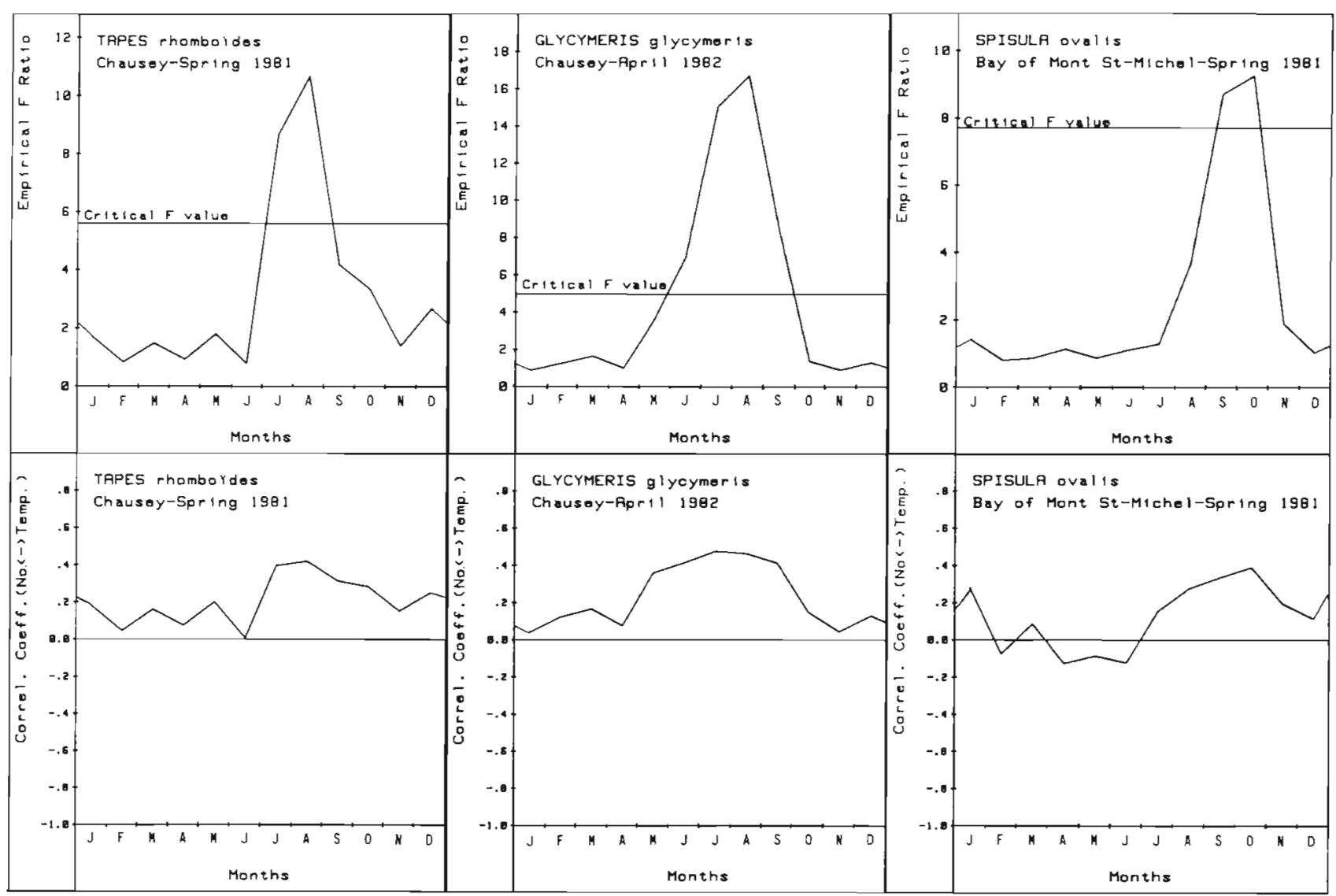

Fig. 3. Tapes rhomboïdes, Glycymeris glycymeris, and Spisula ovalis. Correlation between temperature anomalies and annual recruitments, and their significance

\section{RESULTS}

\section{Recruitment and temperature anomalies}

For each of the $12 \mathrm{mo}$, independently of one another, the bilinear model described by Eqn (2) has been fitted according to the least squares algorithm to the empirical data listed in Table 2. Fig. 3 shows the evolution of the empirical partial correlation coefficient between temperature anomaly and intensity of recruitment when successive months are considered. The concomitant variations of the F-ratio allow the determination of periods which seem most determinant. A similar and relatively strong pattern can be seen for the 3 species. First, the abundance of year-classes is positively correlated with nearly all the monthly thermal anomalies; moreover, this correlation becomes significant, for a particular month, at the $95 \%$ level of confidence, during 2 consecutive months only: July and August for Tapes rhomboïdes and Glycymeris glycymeris, September and October for Spisula ovalis. However, if an overall test is made to a global $95 \%$ level of confidence, only G. glycymeris exhibits a significant
Table 2. Tapes rhomboïdes, Spisula ovalis, and Glycymeris glycymeris. Observed strength of different year-classes, as measured by their scores in the whole sample. These scores correspond respectively to areas of $4.7 \mathrm{~m}^{2}$ for $T$. rhomboides. $3.7 \mathrm{~m}^{2}$ for $S$. ovalis and to an unknown area for the dredged $G$ glycymeris

\begin{tabular}{|cccc|}
\hline Year-class & $\begin{array}{c}\text { Tapes } \\
\text { rhomboïdes }\end{array}$ & $\begin{array}{c}\text { Spisula } \\
\text { ovalis }\end{array}$ & $\begin{array}{c}\text { Glycymeris } \\
\text { glycymeris }\end{array}$ \\
\hline 1980 & 88 & 330 & - \\
1979 & 105 & 51 & - \\
1978 & 30 & 50 & - \\
1977 & 97 & 44 & - \\
1976 & 158 & 33 & 108 \\
1975 & 30 & 10 & 71 \\
1974 & 12 & 1 & 46 \\
1973 & 6 & & 14 \\
1972 & 6 & & 2 \\
1971 & 8 & & 3 \\
1970 & & & 3 \\
1969 & & & 4 \\
1968 & & & 3 \\
1967 & & & 3 \\
1966 & & & 3 \\
1965 & & & 3 \\
1964 & & & \\
\hline
\end{tabular}


effect of temperature anomalies. These periods can be compared with the reproductive cycle of the 3 species, especially with spawning periods, determined in situ by a sudden drop in percentage of mature ovocytes in the gonad. For $T$. rhomboides, a major spawning period has been recorded in mid-summer by Blanchard et al. (1987) in the Gulf of St. Malo and Glemarec \& Bouron (1978) in the Glénans archipelago off the Atlantic coast of Brittany, France. For G. glycymeris and $S$. ovalis, 2 major spawning periods are referred to: May and July for G. glycymeris (Morvan 1986) and July and September for $S$. ovalis (Blanchard 1982). The

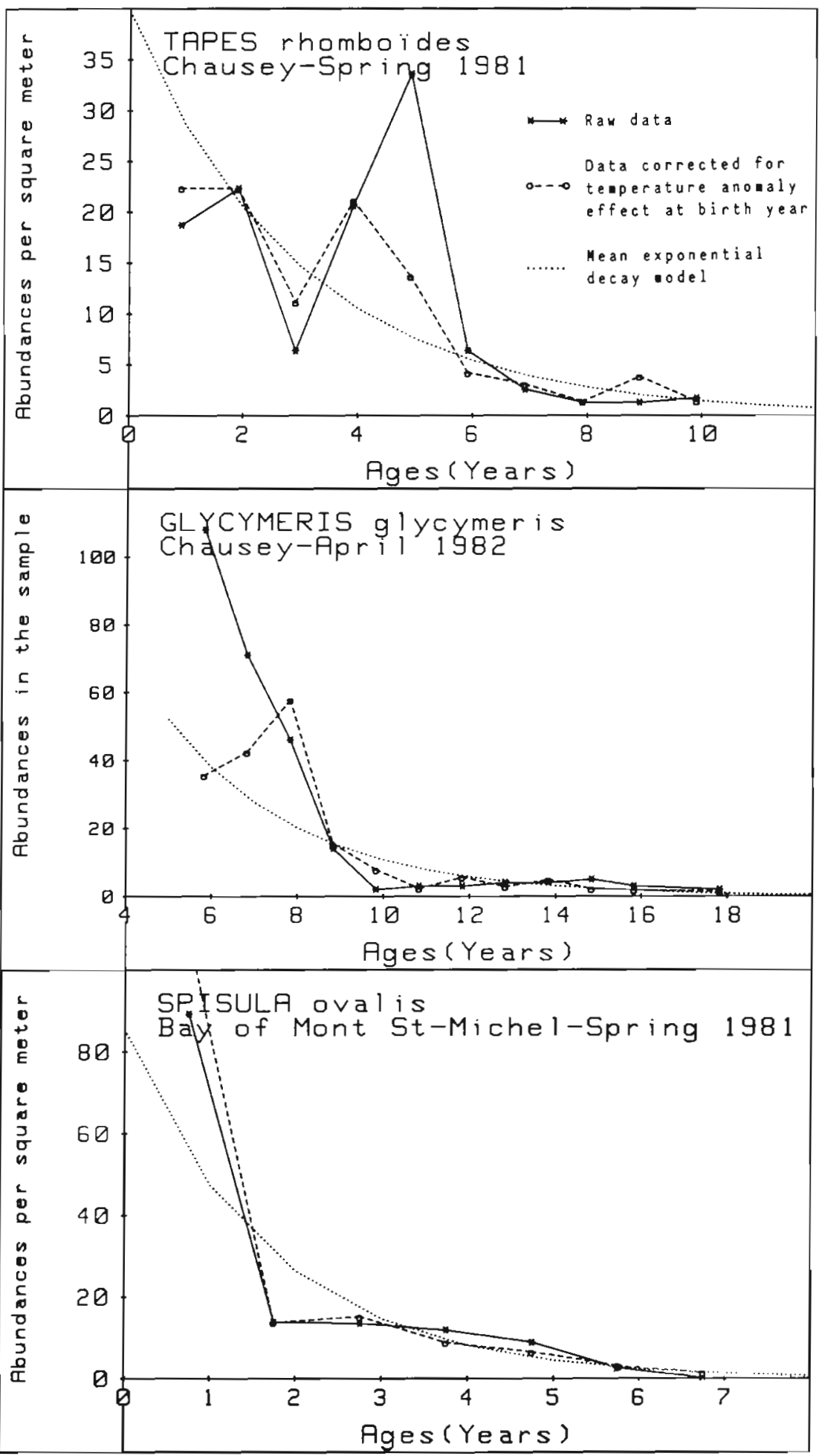

Fig. 4. Tapes rhomboïdes, Glycymeris glycymeris, and Spisula ovalis. Observed, observed but corrected for temperature influence, and mean theoretical demographic structure of populations 
Table 3. Tapes rhomboïdes, Glycymeris glycymeris and Spisula ovalis. Estimated demographic parameters of Eqn (1) with confidence intervals at the $95 \%$ level

\begin{tabular}{|lccc|}
\hline & $\begin{array}{c}\text { Tapes } \\
\text { rhomboïdes }\end{array}$ & $\begin{array}{c}\text { Glycymenis } \\
\text { glycymeris }\end{array}$ & $\begin{array}{c}\text { Spisula } \\
\text { ovalis }\end{array}$ \\
\hline $\mathrm{N}_{\circ}\left(\right.$ ind $\left.\mathrm{m}^{-2}\right)$ & $41[18,95]$ & - & $87[25,313]$ \\
$\alpha\left({ }^{\circ} \mathrm{C}^{-1}\right)$ & $0.75[0.19,1.31]$ & $0.84[0.26,1.43]$ & $1.03[0.07,1.99]$ \\
$\mathrm{Z}\left(\mathrm{yr}^{-1}\right)$ & $0.33[0.20,0.47]$ & $0.29[0.18,0.40]$ & $0.59[0.26,0.93]$ \\
\hline
\end{tabular}

'climatic' decisive period for the strength of a particular year class seems to be the month following the last major spawning period, i.e. a period of pelagic larval life.

Using only the month associated with the highest $F$ value in the statistical analysis, we can derive estimations for parameters $\alpha$ and Z of Eqn (1), and also an estimation of the initial density of the mean year-class of Tapes rhomboïdes and Spisula ovalis, for which absolute densities have been determined by the use of a grab. Table 3 gives mean values and $95 \%$ confidence intervals for these demographic parameters. Visual appraisal of the effect of interannual fluctuations of recruitment can be obtained by 'correcting' each individual year-class for the temperature effect at its birth-year. In Fig. 4, the observed demographic structure, the 'temperature-corrected' structure and the mean theoretical model are presented for the 3 species. Apart from giving a possible climatic explanation for interannual fluctuations, the complete model corresponding to Eqn (1) provides a better estimation of the instantaneous rate of decay, $Z$, than the simple exponential model. This is particularly evident when the youngest or oldest year-classes are strongly abnormal. Due to the weight of extreme points in linear regression, these year classes can alter the slope estimate, $Z$, considerably.

\section{Growth and temperature anomalies}

As previously mentioned, calculation of annual growth anomalies implies estimation of the mean growth pattern of each individual. The scattergrams of individual $\left(\mathrm{K}, \mathrm{L}_{\infty}\right)$ pairs in Fig. 5 show how important the natural variability of growth among a population can be. The elliptical contours added to Fig. 5 contain $95 \%$ of possible pairs $\left(K, L_{\infty}\right)$, assuming for these 2 variables a bivariate Gaussian distribution with the observed variances-covariances matrix. While this assumption is well-founded for Tapes rhomboïdes, it seems to be only a rough approximation for the other 2 species: the real $95 \%$ confidence region seems to be 'banana-shaped', revealing non-linear interactions.
Fig. 6 shows the linear correlation between the overall estimation of $K$ and the various monthly temperature anomalies, with the significance measured by the empirical $F$ ratio. In the same way as for recruitment variations, but with considerably lower significance, a similar pattern can be proposed for the 3 species, as follows:

A period of positive correlation exists at the end of autumn and beginning of winter. Very acute only for Tapes rhomboïdes (in Oct and Nov), but very weak and coming later on for the other 2 species (Nov-Dec for Spisula ovalis and Jan-Feb for Glycymeris glycymeris), this thermal stress corresponds to the classical effect of temperature on metabolism and growth. A relatively warm autumn will stimulate growth before winter ring marking.

On the other hand, in summer (and also spring for Glycymeris glycymeris and Spisula ovalis), growth is inversely correlated with thermal anomalies. For no species however, does this phenomenon seem to affect growth in a statistically significant manner. To be noted however is the agreement between the number of periods of maximum negative correlation and the number of main spawning periods, as already mentioned: one period (Jun, Jul, Aug) for Tapes rhomboïdes, and 2 periods for the other 2 species: MayJune and September-October for G. glycymeris, June and September for $S$. ovalis. Moreover, except for the September-October period for G. glycymeris, all these periods precede or coincide with the spawning periods. The fact that during these periods the correlation of growth with temperature becomes negative implies that the major influence of temperature during this phase is not the direct, stimulating one, but an indirect, more complex one. The occurrence of gamete maturation during these periods can provide a plausible explanation: due to the particular sensibility of gametogenesis to temperature (Lubet 1976), the balance between growth metabolism and gamete formation can be thermally displaced, abnormally high temperatures stimulating gonadic growth and slowing down somatic growth.

\section{DISCUSSION}

As noted in the introduction, many authors have found a positive correlation between temperature anomalies and magnitudes of recruitment, especially in regions near the northern limit of distribution area of the species. Among fishes and crustaceans, the following well-studied species can be cited: cod off the west Greenland coast (Hermann et al. 1965), herring off south-western Alaska (Cushing 1982), sprat in the Skagerrak (Lindquist 1978), and American lobster in 


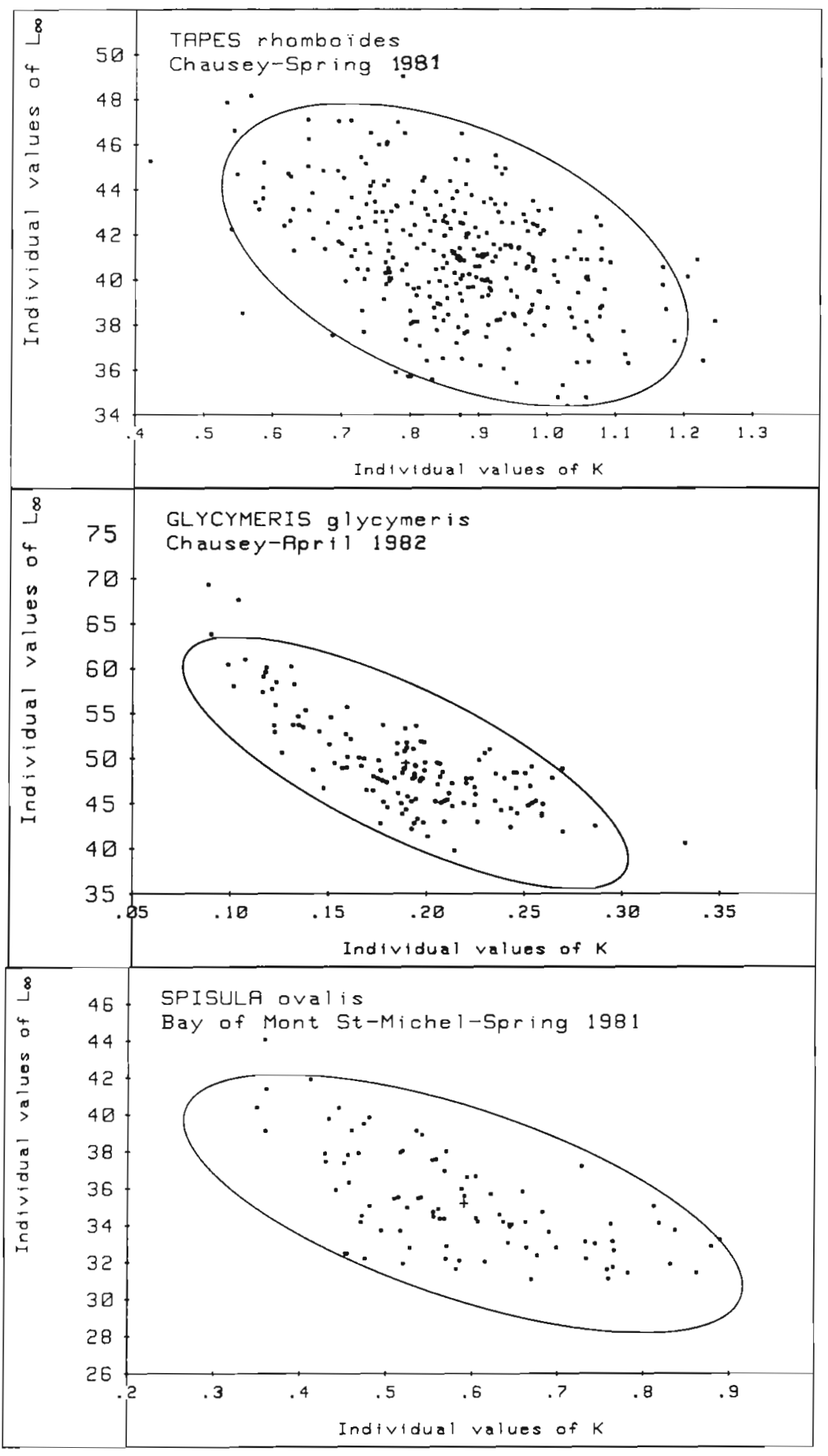

Fig. 5. Tapes rhomboïdes, Glycymeris glycymeris, and Spisula ovalis. Scattergrams of individual estimated $\left(K, L_{\infty}\right)$ pairs

the Gulf of Maine (Dow 1976). Several commercially exploited molluscs have also revealed such temperature dependence: Haliotis tuberculata in the English Channel (Forster et al. 1982), Placopecten magellanicus in the Bay of Fundy (Dickie 1955), Mercenaria mercenaria and Crassostrea virginica in the Gulf of
Maine (Dow 1972), native Ostrea edulis in the Limfjord (Spärck 1949), and Crassostrea angulata and C. gigas on the French Atlantic coast (Heral et al. 1987). While Dow $(1972,1976)$ used annual temperature means only, all the previously cited authors showed, by using monthly means, that a period of only a few months was 


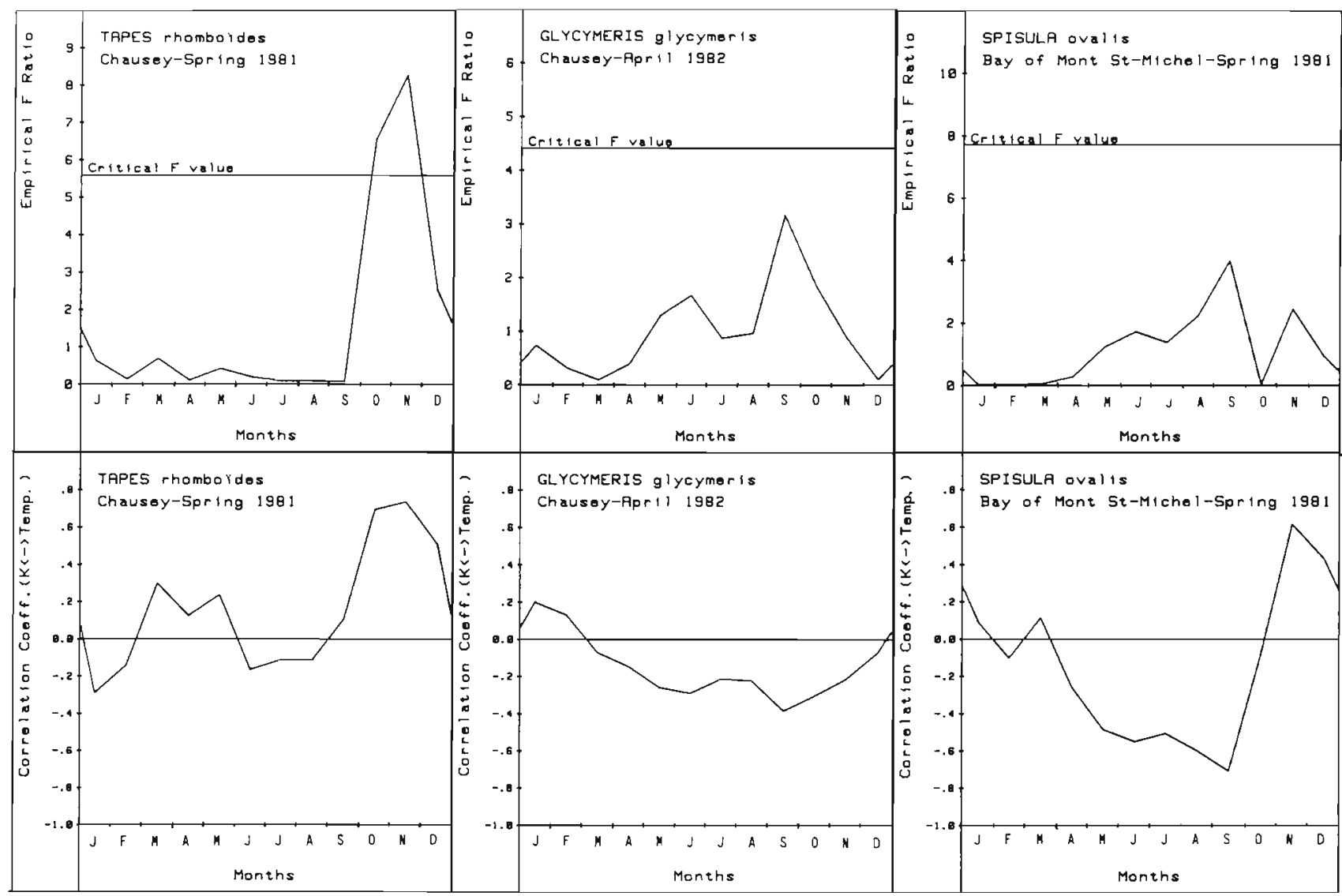

Fig. 6. Correlation between temperature anomalies and annual growth estimation (Von Bertalanffy K parameter)

determinant relative to recruitment success. This period regularly coincides with the spawning and/or pelagic larval stage, as demonstrated for the 3 lamellibranchs examined in this paper. For Pecten maximus in Bay of St. Brieuc (France), Boucher et al. (1985) showed that temperature may have a direct effect on recruitment: if July is abnormally cold, the necessary $16{ }^{\circ} \mathrm{C}$ stimulus for spawning is reached later than complete maturity of ovocytes. When they are finally released, eggs may then have lost some part of their qualities. As mentioned in the introduction, other authors invoke temperature effects during the larval stage.

Studies on relationships between long series temperature observations and in situ estimated growth are more scarce. Dementyeva \& Mankevich (1965) found a positive correlation ( $r=0.71$ ) between the size of particular age-classes of cod and the total average temperatures during the feeding periods' in the Barents Sea, while Shafee (1980), using a multilinear approach, showed that the instantaneous Von Bertalanffy $\mathrm{K}$ parameter was positively correlated with the instantaneous temperature. We find here again the traditional positive effect of temperature on growth.
On the contrary, mean annual growth cannot automatically be considered as positively correlated with annual mean temperature, because of the simultaneous involvement of opposing phenomena. For instance, Jones (1981) found that the mollusc Spisula solidissima off the New Jersey coast showed greater mean annual growth when annual mean temperature was rather low. Although Jones did not put forward any causal explanation, the hypothesis can be proposed that summer and fall temperatures in this area are too high for this species, more especially as Jones (1981) also found that good recruitment was linked to rather cold years. Another important phenomenon interfering with pure somatic growth is gametogenesis. Mann \& Glomb (1978) have shown that increasing temperature increases the rate of somatic growth of Tapes philippinarum below $12^{\circ} \mathrm{C}$, but slows it above, because of the rapid start of gametogenesis. The same conclusion can be drawn from studies by Ohba (1959) and Holland \& Chew (1974) on the same species. It is well established for several bivalve species (Lubet 1976) that gonadic growth becomes significant only above a temperature threshold characteristic of the species and the geographic situation, but few authors 
have studied implications of gametogenesis upon somatogenesis. In contrast to the conclusions of Mann \& Glomb (1978) and the hypothesis advanced in this paper, de Wilde (1975) found that Macoma balthica from the Holland coast developed gametogenesis without slowing its growth. It appears that the observed relation between temperature and growth anomalies results from the complex interaction of somatic growth stimulation (if temperature lies below the optimal value) and gonadic growth obeying a threshold-like stimulation. The geographic location of the population will of course be determinant in the relative balance between these competitive components. The fact that in the Gulf of St. Malo, the density at recruitment of Tapes rhomboïdes, Glycymeris glycymeris and Spisula ovalis is positively correlated with temperature anomalies is consistent with the median latitudinal position of the English Channel in the distribution ranges of these 3 species (Blanchard 1985). This result implies that summer temperatures in this area are not usually high enough to be growth inhibiting, and corroborates the hypothesis that the negative correlation between growth and temperature anomalies is mainly due to competition between gametogenesis and somatogenesis.

Acknowledgements. The authors thank M. M. Blanchard (Ifremer) who carried out sampling operations, and M. P. Chardy (Ifremer) for the aging of Glycymeris glycymeris. They are grateful to $M$. A. Agoumi (Electricité de France. Direction des Etudes et Recherches) for the temperature calculations he kindly provided for this work.

\section{LITERATURE CITED}

Agoumi, A. (1982). Modélisation du régime thermique de la Manche. Thèse de Docteur Ingénieur, Ecol. Nat. Ponts et Chaussées, Paris

Blanchard, M. (1982). Dynamique de deux populations des sables grossiers: Tapes rhomboïdes et Spisula ovalis. In: Chardy, P. (ed.) Etude écologique d'avant-projet du site marémoteur du Golfe Normano-Breton: le benthos subtidal. Rapp. contrat EDF/CNEXO 80/2233, CNEXO/COB/ ELGMM publ., Brest, p. 36-73

Blanchard, M. (1985). Espèces zoobenthiques. Etude bibliographique de quelques espèces planctoniques et benthiques littorales de la Manche, Vol. 3. Rapp. IFREMER/ Centre de Brest/DERO/EL, Brest

Blanchard, M., Chardy, P., Dreves, L., Guennegan, Y. (1983). Les bivalves. Etude écologique du site Cotentin Centre, Chap. III. Rapp. contrat EDF/CNEXO 83/2959 - CNEXO/ COB/ELGMM publ., Brest

Blanchard, M., Morvan, C., Quiniou, F. (1987). Dynamique de population de la palourde rose Tapes rhomboïdes (Pennant 1977) dans le Golfe Normano-Breton. Haliotis 15 (in press)

Boucher, J., Arzel, P., Buestel, D. (1985). Causes probables de variations du recrutement de la coquille St-Jacques identifiées en baie de St-Brieuc. In: Déterminisme du recrute- ment. Séminaire de Nantes, 2-4 juillet 1984, Rapp. IFREMER/DRV-85-01/D, Nantes, France, Contrib. N ${ }^{\circ} 23$

Cushing, D. H. (1970). The regularity of the spawning season in some fishes. J. Cons. int. Explor. Mer 33: 81-97

Cushing, D. H. (1982). Clinate and fisheries. Academic Press, London

Dementyeva, T. F., Mankevich, E. M. (1965). Changes in the growth rate of the Barents Sea Cod as affected by environmental factors. Spec. Publs int. Comm NW Atlant. Fish. 6: $571-577$

Dickie, L. M. (1955). Fluctuations in abundance of the giant scallop Placopecten magellanicus (Gmelin) in the Digby area of the Bay of Fundy. J. Fish. Res. Bd Can. 12 (6): $796-856$

Dickson, R. R., Pope, J. G., Holden, M. J. (1973). Environmental influences on the survival of North Sea Cod. In: Blaxter, J. H. S. (ed.) The early life history of fish. Springer Verlag, Heidelberg, 69-80

Dow, R. L. (1972). Fluctuations in Gulf of Maine of sea temperature and specific molluscan abundance. J. Cons. int. Explor. Mer 34 (3): 532-534

Dow, R. L. (1976). Effects of sea-surface temperature cycles on landings of America, European and Norway lobsters. J. Cons. int. Explor. Mer 38 (2): 271-272

Forster, G. R., Potts, G. W., Swinfen, R. (1982). Changes in the ormer populations of Guernsey and Jersey. J. mar. biol. A.ss. U. K. 62: $717-727$

Fritts, H. C. (1976). Tree rings and climate. Academic Press, London

Glemarec, M. Bouron, D. (1978). Evolution de la la maturité sexuelle chez six espèces de bivalves des Glénans Haliotis 9 (1): 45-48

Heral, M., Prou, J., Deslous-Paoli, J. M. (1987). Influence des facteurs climatiques sur la production conchylicole du bassin de Marennes-Oléron. Haliotis 15 (in press)

Hermann, F., Hansen, P. M., Horsted, S. A. (1965). The effect of temperature and currents on the distribution and survival of cod larvae at West Greenland. Spec. Publs. int Commn NW. Atiant. Fish. 6: 389-409

Holland, D. A., Chew, K. K. (1974). Reproductive cycle of the Manila clam (Venerupis japonica) from Hood Canal Washington. Proc. natn. Shellfish. Ass. 64: 53-58

Jones, D. S. (1981). Annual growth increments in shells of Spisula solidissima record marine temperature variability Science 211: 165-167

Leroy-Ladurie, E. (1983). Histoire du climat depuis l'an mil. Collection Champs, Flammarion, Paris

Lindquist, A. (1978). A century of observations on sprat in the Skagerrak and the Kattegat. Rapp. P-v. Réun. Cons. int. Explor. Mer 172: 187-196

Loosanoff, V. L., Miller, W. S., Smith, P. B. (1951). Growth and setting of larvae of Venus mercenaria in relation to temperature. J. mar. Res. 10 (1): 59-81

Lubet, P. (1976). Ecophysiologie de la reproduction chez les mollusques lamellibranches. Haliotis $7: 49-55$

Mann, R., Glomb, S. J. (1978). The effect of temperature on growth and ammonia excretion of the Manila clam Tapes japonica. Estuar. coast. mar. Sci. 6: 335-339

Martin, W. R. Kohler, A. C. (1965). Variation in recruitement of Cod (Gadus morhua L.) in southern ICNAF waters, as related to environmental changes. Spec. Publs int. Commn NW. Atlant. Fish. 6: 833-846

Morvan, C. (1986). Sexualité de quatre mollusques bivalves dans le Golfe Normano-Breton. Rapp. Contrat IFREMER UBO 85/243/4007, Brest, p. 1-25

Ohba, S. (1959). Ecological studies in the natural population of a clam, Tapes japonica, with special reference to sea- 
sonal variation in the size and structure of population and to individual growth. Biol. J. Okayama Univ. 5: 13-42

Shafee, M. S. (1980). Application of some growth models to the black scallop, Chlamys varia (L.) from Lanveoc, Bay of Brest. J. exp. mar. Biol. Ecol. 43: 237-250

Spärck, R. (1949). Fluctuations in the stock of oyster (Ostrea edulis) in the Limfjord in recent time. Rapp. P-v. Réun. Cons. int. Explor. Mer 128, II 5: 27-29
Tomlinson, P. K. (1970). Programme BGC 3. Von Bertalanffy growth curve fitting. In: Abramson, N. J. (compiled by) Computer programs for fish stock assessment, Chap. 2.1 to 2.4. FAO Fish. Tech. Pap. 101, Roma

Wilde, de, P. A. W. J. (1975). Influence of temperature on behaviour, energy metabolism and growth of Macoma balthica (L.). In: Barnes, H. (ed.) Proc. 9th Europ. mar. biol. Symp. Aberdeen University Press, Aberdeen, p. 239-256

This article was submitted to the editor; it was accepted for printing on November 28, 1986 